\title{
Contemporary Christianity: Interconfessional and Intercultural Challenges. Parish Ministry and Religious Pluralism
}

Cristianismo Contemporâneo: Desafios Interconfessionais e Interculturais. Ministério Pastoral e Pluralismo Religioso

Graham GERALD MCGEOCH (Da

\begin{abstract}
This reflection is based on 10 years' experience of parish ministry in the Church of Scotland. While offering a territorial ministry - even in overseas former missionary churches - I became deeply aware of religious pluralism in each parish. I explored this religious pluralism in relation to Jewish and Muslim communities living in the parishes that I served. In particular, in dialogue and sharing with imams and rabbis, we explored interconfessional and intercultural challenges of living together and worshiping together. I have invited rabbis and imams to 'preach' during public worship; likewise, I have been invited to offer reflections in synagogues and mosques during times of 'holy prayer'. This reflection documents the interconfessional and intercultural challenges of parish ministry and religious pluralism.
\end{abstract}

Keywords: Parish Ministry. Religious Pluralism. Christianity. Judaism. Islam.

\section{Resumo}

Esta reflexão é fundamentada em 10 anos de experiência de ministério pastoral na Igreja da Escócia. Enquanto oferecendo um ministério territorial - até em igrejas missionários no estrangeiro - eu me tornei profundamente consciente do pluralismo religioso em cada paroquia. Eu investiguei este pluralismo religioso em relação às comunidades judaicas e muçulmanas que viveram nas paroquias que eu servi. Especificamente, em diálogo e compartilhando com imams e rabinos, investigamos juntos os desafios interconfessionais e interculturais de convivência e adoração conjunta. Eu tenho convidado rabinos e imams para 'pregar' durante a liturgia pública;

a Faculdade Unida de Vitória (FUV), Vitória, ES, Brazil. PhD, e-mail: graham@fuv.edu.br 
do mesmo modo, eu tenho sido convidado para oferecer reflexões em sinagogas e mesquitas durante momentos de 'oração santa'. Esta reflexão documenta os desafios interconfessionais e interculturais do ministério pastoral e pluralismo religioso.

Palavras-chave: Ministério Pastoral. Pluralismo Religioso. Cristianismo. Judaísmo. Is/ã.

\section{Introduction}

For 10 years, I served as a parish minister in Europe ${ }^{1}$. Currently, I teach Theology and Religious Studies in Latin America ${ }^{2}$. This is a personal reflection based on the context of my parish work in Europe, specifically in Glasgow, Lisbon and Edinburgh. In each city, I served churches in the urban centre. I became deeply aware of the religious pluralism shaping our urban life. I was particularly drawn to explore relationships between the churches that I served and the Jewish and Muslim communities within those parishes.

Scotland has a national - not established - church. In its Declaratory Articles (an Act of the Westminster Parliament), the Church of Scotland is charged to bring the ordinances of religion to the people of Scotland in all its parts. This is a legacy of the Reformation settlement in Scotland. The Kirk - "a term used to designate the reformed Church of Scotland which today is Presbyterian in government" (MACDONALD, 2017, p. 1) - was affirmed by the Scottish Parliament in 1560, and this magisterial Reformation and civil decision influences the Church of Scotland's selfunderstanding. Marjory MacLean has noted that a magisterial Reformation is one based on a religious change through the decision of a civil magistrate (MACLEAN, 2009, p. 54). In Scotland, it mattered that the magistrate was Christian and Protestant; and it mattered that Monarchs and Parliaments were Protestant.

The legacy of Reformation and the charge to bring the ordinances of religion to the people of Scotland in all its parts is made manifest in the parish ministry exercised by the Church of Scotland throughout the national territory. In a parish church members worship and witness together from a breadth of theological positions. This is a major difference from most Protestant churches in Brazil, which tend to draw tighter boundaries with

\footnotetext{
${ }^{1}$ I am an ordained Minister of Word and Sacrament of the Church of Scotland.

${ }^{2}$ I teach Theology on the undergraduate programme and Religious Studies on the postgraduate programme at Faculdade Unida de Vitória, Brazil.
} 
regard to theological belonging and believing. The Reformation legacy is also made manifest in the missionary churches established by Scots in overseas territories. Again, in these missionary churches, it is often questions of language and culture which hold people together rather than issues of theological affinity. In some senses, this kind of parish ministry (including its reflection in the practice of missionary churches in overseas territories) is the distinctive calling of the Church of Scotland, and it includes a strong element of internal theological plurality in the life of the parish church.

Obviously, there are other churches in Scotland. The Roman Catholic Church plays a significant, and growing, role across the country. There are significant pockets of Episcopalianism. There are other churches, notably Baptist and Methodist, associated with the various expressions of Protestant Christianity. Some churches, like the congregational churches, have a long history in the Scottish religious landscape. Others are newer, particularly Pentecostal churches strongly associated with 'new Scots' and the waves of migration. There are also significant other religious communities, including Jewish and Muslim communities. The Church of Scotland is fully committed to ecumenical relations and interfaith dialogue and co-operation.

One of the charges that I served - Lisbon, Portugal - is fruit of the missionary endeavors of Scots. The Free Church of Scotland mission established the charge in 1866 (ORDERS, 1990). In the Act of Union (1921), the Church of Scotland not only reestablished its national vocation in the exercising of a territorial ministry within Scotland, it also inherited various Scottish Protestant missionary churches. St Andrew's Presbyterian Church in Lisbon is Portugal's oldest Presbyterian church. Curiously, both the Evangelical Presbyterian Church of Portugal and the (Anglican) Lusitanian Church in Portugal trace their beginnings to this Scottish Presbyterian church. It also has a place in church history in the Americas, due to the presence of Robert Reid Kalley in Lisbon and Madeira before his expulsion and subsequent arrival in the Americas (TESTA, 2005; PURVES, 1940).

Whether as a national church or missionary church, the parishes of the Church of Scotland seek to bring the ordinances of religion to the people of Scotland in all its parts, and firth of Scotland too. Obviously, within Europe, the vast majority of populations express no formal religious affiliation. Curiously, the records of the Church 
of Scotland regarding membership consistently document lower numbers of affiliation than those revealed in government census figures. Alongside the vast swathes of the population who express no formal religious affiliation, there are many vibrant minority faith communities. Christianity, Islam and Judaism are the focus of this reflection.

\section{Religious Pluralism}

Diana Eck is perhaps amongst the leading academic voices in relation to religious pluralism. The world renowned Religious Pluralism project at Harvard University, founded and led by her, charts her engagement with themes of religious pluralism. In her Gifford Lectures in 2009, entitled 'The Age of Pluralism', she noted that religious pluralism represents one of the great changes for (Western) societies. Migration and communication have brought greater proximity, particularly amongst religions. This is reflected in the Church of Scotland parishes where many religions (and none) find expression. Christians, let alone Protestants no longer exclusively populate parish populations. It is an unimaginable situation for those who led the Scottish Reformation.

In her Gifford Lectures, Diana Eck outlined the challenges of the question, "how do we relate to one another?' in relation to three groups: scholars, citizens and faith communities. I am aware of the ongoing scholarly debates about religious pluralism, and particularly the growing influence of questions of hermeneutics in the fields of theology and religious studies with regard to navigating religious pluralism. Catherine Cornille's work is an excellent reference in the field ${ }^{3}$. In Brazil, I can cite the work of the Methodist theologian Claudio Ribeiro (RIBEIRO, 2014).

However, in this reflection, I would like to focus on religious pluralism as it affects citizens and faith communities. In terms of faith communities, I am focusing particularly on the Church of Scotland parish model that seeks to bring the ordinances of religion to the people of Scotland in all its parts, and which also operates a parish model in Scottish missionary churches. We might ask, does a 'national church' help or

\footnotetext{
${ }^{3}$ Catherine Cornille's 5 volume work published as 'Interreligious Dialogue Series Books' draws leading scholars from across the world and from different fields into reflections on religious pluralism.
} 
hinder the framing of narratives of religious pluralism? Furthermore, we might explore, how does a 'national church' bring the ordinances of religion to Jews or Muslims"?

Before turning to these questions, I would like to set out my understanding of religious pluralism. Religious pluralism is a fairly new phenomenon whereby a large majority of human beings are now aware of the 'religious other' because the 'religious other' lives in the same society, often the same street. This is not to say that 'religious pluralism' did not exist until fairly recently. There are examples from Asia, Africa and Latin America of 'religious pluralism' stretching back centuries. Not to mention various moments of religious pluralism in European history.

However, the growing awareness of religious pluralism amongst citizens and faith communities is related to the more visible presence of the 'religious other', whether manifest in buildings, habits or beliefs. This more visible presence is sometimes related to the revanche de Dieu theory put forward by social sciences, countering the previous assumption that religion would simply disappear from public life. As Eck, Cornille and others have pointed out, both theories from the social sciences - 'secularisation' and revanche de Dieu - are deeply problematic in the first instance. This is not the place for that scholarly debate.

\section{Religious Pluralism in Parish Life}

Let me begin at the end.

Pentecost is an important day in the Christian liturgical year. It falls 50 days after Easter and celebrates the coming of the Holy Spirit as described in the book of Acts. (That it also recounts the first disciples (all Jews) partaking Shavuot, a Jewish festival marking the harvest of the first fruits and recalling the Exodus narrative, is not often alluded to in parish worship services). On Pentecost, in my Edinburgh parish, the imam from the mosque in the parish rose to address the gathered congregation at the parish church. It was a remarkable moment for a variety of reasons. I cannot go into all of

\footnotetext{
${ }^{4}$ The reality of religious pluralism in parishes is obvious broader than the religions here mentioned. As noted in the Introduction, this reflection focuses on exploring relationships between the churches that I served and the Jewish and Muslim communities within those parishes.
} 
those reasons here ${ }^{5}$. The basic point is that at a Pentecost service in a Church of Scotland parish church - a service led by the parish minister, alongside the Roman Catholic Vicar General for the Diocese - the imam rose to address the gathered congregation after the Roman Catholic Vicar General had announced the gospel.

How did the parish church arrive at this point? Is it simply an expression of citizens' growing awareness of religious pluralism? Is it a Christian theological witness of religious pluralism? Why did the imam, like other imams and rabbis before him and after him, accept the invitation to address a parish church? Is it a Muslim theological witness of religious pluralism ${ }^{6}$ ? Is it simply an expression of citizens' growing awareness of religious pluralism? To understand the question of religious pluralism in relation to parish life, it is necessary now to return to the beginning.

Like many ministers in the Church of Scotland, I began life as a parish minister with a 15-month assistantship under the guidance of an experienced minister. My assistantship was at the High Kirk or St Mungo's in the centre of Glasgow, Scotland's largest city. Amongst the many words of wisdom shared by the minister, Laurence Whitley, two things have stayed with me through my parish ministry. Firstly, early on in my assistantship Laurence advised me to read as much as possible, and to read as widely as possible. 'It helps the sermon', he quipped. Secondly, he consistently emphasized with me the need for a city centre parish church to find ways of actually being the parish church. 'It is the bread and butter of who we are as a Church of Scotland', he would say.

Laurence Whitley's vision for a city centre parish church deeply influenced my subsequent thinking about parish ministry. It also drew my attention to the need for a parish church to be in relationship with those who resided within the parish, and, in the case of a city centre parish church, with those who passed through the parish. For example, large pockets of social housing and the accompanying hidden poverty mark the parish of the High Kirk or St Mungo's in Glasgow. The parish also looks very different at 3

\footnotetext{
${ }^{5}$ For a fuller description of the content of this address see: RABBANI, 2020.

${ }^{6}$ Frequently Religious Studies literature refers to that the fact that the discipline of 'theology' is understood differently by Christianity and Islam, and that it has a different importance in each religion. Again, this is not the place for this scholarly debate.
} 
o'clock in the afternoon from 3 o'clock in the morning. The congregation is 'gathered', that is to say the vast majority of Sunday worshippers come from outside the parish.

Before turning to Diana Eck's question addressing religious pluralism, a key question therefore becomes, who are the people who live, work and seek leisure or refuge in the parish of the church? A city centre parish church rests on a rhythm of fluidity rather than stability. Many people who are in the parish at any given moment are not necessarily rooted in the life of the parish. Only after this discovery of fluidity can one turn to Eck's question: how do we relate to each other in this particular parish? In the case of a parish in the city centre of Scotland's largest city, religious pluralism quickly becomes apparent. The 'status' of the High Kirk or St Mungo's in the city also means that it has the capacity to engage directly with religious and civic leaders who do not reside, work or seek leisure/refuge in the parish.

For example, Glasgow's Central Mosque often approached this parish church with invitations to participate in mosque programmes. The Central Mosque in Glasgow is not located in the parish of the High Kirk or St Mungo's, but rather across the River Clyde in the Parish of Gorbals Church. In this case, it is possible to affirm that the Central Mosque 'religiously read' the Christian presence in the city in Muslim terms and interpreted the High Kirk or St Mungo's as the 'Central Church".

This touches on the very difficult question of 'representation' of religions in the face of religious pluralism ${ }^{8}$. Who speaks on behalf of a religion? Moreover, in the case of religions like Christianity, Islam and Judaism which have 'religious pluralism within', we might ask which Christianity, Judaism or Islam is being 'represented'? In the case of inter-religious dialogue and co-operation, we might also reflect on gender. I am aware that, as a man, it is perhaps easier to engage imams and rabbis and negotiate patriarchal buildings, habits and customs of religious leaders than it would be for a woman minister. It also seems important to remember that Christianity, Islam and

\footnotetext{
${ }^{7}$ I also undertook a period of training for ministry in the Gorbals parish. There was no ongoing contact with the Central Mosque, and no invitations were ever (to my knowledge) issued to this parish church by the Central Mosque.

${ }^{8}$ Kwok Pui Lan has explored this in her book, Globalization, Gender, and Peacebuilding: The Future of Interfaith Dialogue (2012).
} 
Judaism do not conceive of themselves as 'religions' in the same way that the fields of comparative religion and religions studies sometimes try to define them.

\section{Religious Pluralism in a Mission Church}

From the High Kirk or St Mungo's, I moved to Lisbon, Portugal. This gave me the opportunity to explore parish ministry in new ways ${ }^{9}$. The mission church was established in the old port area of the city following a free-trade agreement between the UK and Portugal, which inserted a 'religious freedom clause' ${ }^{10}$. Thereafter, Portugal and its colonies begin to see the construction of Protestant churches, without a bell tower, and set back from main thoroughfares (as the free-trade agreement dictated). Unlike Scotland, Portugal's Protestant community is a minority. It has also made little contribution to the wider construction of Portuguese identity. Its presence has been restricted to 'foreigners', 'families' and 'chaplaincies'. It has also been persecuted.

While Spain and Portugal have enjoyed long periods of religious pluralism in their histories, 1492 marks a decidedly different approach to 'the religious other'. It is often remembered as the date marking the encounter between 'old' and 'new' worlds. It is also the year in which Christianity consolidates its hegemony in the Iberian Peninsula with the expulsion of Jews and Muslims. In subsequent years, the Inquisitions will ensure ongoing persecution of Jews, Muslim and Protestants throughout Spanish and Portuguese territories. After 1492, and throughout the Inquisitions, religious pluralism is interpreted as a danger to political unity in the newly emerging configuration which will become 'the nation state' some centuries later.

In Lisbon, I quickly perceived that the lived experience of Protestants, Jews and Muslim (as persecuted minorities) drew each faith group into expressing common

\footnotetext{
${ }^{9}$ Noting the theological plurality mentioned earlier in relation to parish churches (and mission churches), the Lisbon church had a worshiping congregation that included Anglicans, Baptists, Pentecostals, Presbyterians, Reformed, Roman Catholics, Orthodox, and Salvation Army (and agnostics and atheists). It also included worshipers from many different countries, not all recognized as English-speaking countries. Issues of access to English language and Scottish culture played a more important role in belonging and believing than theology.

${ }^{10}$ The Treaty of Rio de Janeiro in 1810 granted freedom of worship to British subjects in Portuguese territories, and allowed for the construction of chapels or churches as long as they resembled private houses.
} 
stories. On a practical level, my small mission church in Lisbon cultivated relations with the Central Mosque in Lisbon, and with a small Jewish synagogue. This work was fully supported by the Kirk Session, and the Session Clerk - a woman - played an active role in building relations between church, mosque and synagogue. I attended Friday prayers at the mosque, and the imam hosted a group visit by members of the church. (The visit generated wider curiosity in the English-speaking international community, drawing into the group visit people who had no particular connection with mosque or church, some even professing no religious affiliation - citizens and faith communities together, to use the earlier categories of Diana Eck).

In time, the imam attended Sunday worship at church and addressed the congregation on the theme of 'Compassion'. Both mosque and church had become the first religious groups in Portugal to sign the 'Charter for Compassion', the global interfaith movement launched by Karen Armstrong in $2009^{11}$. The "Charter for Compassion', with its golden rule of loving God and neighbour, provided mosque and church with common ground for encounter, dialogue and co-operation.

The mission church was also drawn into dialogue with Rabbi Jules Harlow from New York on his frequent visits to Portugal. Rabbi Harlow nurtured a small group of Jewish people 'reverting' to Judaism after discovering in their family histories that during Portugal's persecution of Jews - which included forcible conversation, or exile or death - many had converted to Christianity to preserve life and property. Rabbi Harlow was to address the congregation at Sunday worship, too. But only after he had invited a small number of the church congregation to attend a Kabbalat Shabbat service at the synagogue. The church insisted on a 50\% women, 50\% men 'representation' and the Session Clerk (a woman) and I were accompanied by two other members of the congregation. On that occasion, Rabbi Harlow had asked me to prepare a message for Jews and Christians squeezed together in the upper room of an old Lisbon baroque house.

I chose to base my message on the contents of the Charta Oecumenica, which at that moment was marking its $10^{\text {th }}$ anniversary (CHARTA OECUMENICA, 2001). The

\footnotetext{
${ }^{11}$ Karen Armstrong launched the 'Charter for Compassion' in a TED talk in 2009. She went on to write a book about compassion (ARMSTRONG, 2010).
} 
Conference of European Churches (which gathers the majority Orthodox, Reformed, Anglican, Free and Old Catholic churches) and the Council of European Bishops' Conferences (of the Roman Catholic Church) signed the landmark European document, Charta Oecumenica (Ecumenical Charter: Guidelines for the growing co-operation among the churches in Europe) in 2001. The preamble to the Charta sets out its designs:

Europe - from the Atlantic to the Urals, from the North Cape to the Mediterranean - is today more pluralist in culture than ever before... In this spirit, we adopt this charter as a common commitment to dialogue and co-operation. It describes fundamental ecumenical responsibilities, from which follow a number of guidelines and commitments. It is designed to promote an ecumenical culture of dialogue and co-operation at all levels of church life, and to provide agreed criteria for this (WENINGER. 2009).

The recognition of pluralism in Europe's culture, and a common commitment by the churches to dialogue and co-operation as a fundamental ecumenical responsibility is fairly remarkable.

It is also important to note that the commitment is not only of high-level church diplomats. The text specifically mentions "all levels of church life". I interpret this to mean "parish life". It is worth noting in passing that this reference to "all levels of church life" was ahead of its time. As awareness of religious pluralism has gained traction in public life since the attacks on US soil in 2001, it has been increasingly noted that interfaith dialogue and co-operation does not always engage the grassroots. At the Annual Conference of Doha Interfaith Dialogue in 2010, Donald Reeves, shared in his lecture an experience of interfaith dialogue: "You all sit round the table on some top floor while on the ground floor a fire is raging!" (REEVES, 2010). The parish is where the fires are raging ${ }^{12}$.

However, what is even more interesting is Article III of the Charter: "Our Common Responsibility in Europe". Paragraph 8 of this article focuses the church on reconciliation of peoples and cultures, stating:

We consider the diversity of our regional, national, cultural and religious traditions to be enriching for Europe. In view of numerous conflicts, the churches are called upon to serve together the cause of reconciliation among peoples and cultures.

\footnotetext{
12 I mention Donald Reeves and his interfaith work because he was to visit Lisbon at the invitation of the church and lead a workshop on Religion and Peacebuilding at the British Embassy. He also led interfaith reflections (spoken and musical) in church settings in the city during his visit.
} 
Paragraph 10 then focuses on Judaism, specifically "Strengthening community with Judaism". It is worth quoting both the paragraph and the commitment of the European churches:

We are bound up in a unique community with the people Israel, the people of the Covenant which God has never terminated. Our faith teaches us that our Jewish sisters and brothers 'are beloved, for the sake of their ancestors; for the gifts and the calling of God are irrevocable' (Rom 11.28-29).

And "to them belong the adoption, the glory, the covenants, the giving of the law, the worship and the promises; to them belong the patriarchs, and from them, according to the flesh, comes the Messiah" (Rom 9.4-5).We deplore and condemn all manifestations of anti-Semitism, all outbreaks of hatred and persecutions. We ask God for forgiveness for anti-Jewish attitudes among Christians, and we ask our Jewish sisters and brothers for reconciliation.

It is urgently necessary, in the worship and teaching, doctrine and life of our churches, to raise awareness of the deep bond existing between the Christian faith and Judaism, and to support Christian-Jewish co-operation.

We commit ourselves

- to oppose all forms of anti-Semitism and anti-Judaism in the church and in society; - to seek and intensify dialogue with our Jewish sisters and brothers at all levels (CHARTA OECUMENICA, 2001, III.10).

It is not possible to address fully the theological implications of this part of the Charta Oecumenica in relation to Judaism in Europe. However, it has implications for parish ministry: for citizens and faith communities. The Charta Oecumenica clearly navigates a European narrative that moves from Reformation and Inquisition to plurality, from exclusion to reconciliation, from history to theology. Religious pluralism is about how we relate to each other in the present, in a new situation, as Diana Eck points out. However, religious pluralism also calls us to remember rightly our past, and to use that historical memory for the healing of the nations. This can really only be done by entering into relationship with the religious other in a religiously plural society. It is important that parish church, mosque and synagogue play their role, recognising religious pluralism within their communities as well as religious pluralism amongst different religious (and non-religious) communities. 


\section{Religious Pluralism, Parish Life, Public Square}

From Lisbon, I moved to Edinburgh, Scotland's capital city. Like Brazil, Scotland has a big industrial city which dominates economic and cultural life, but which is not the capital city. Edinburgh and Glasgow are $70 \mathrm{~km}$ apart in Scotland's densely populated 'central belt'. However, they are very different cities. Again, I moved to a city centre parish at the Eastern gateway to Edinburgh's UNESCO world heritage New Town.

The parish church building was built in 1822 by the city of Edinburgh during the building of the New Town ${ }^{13}$. In other words, following the Reformation settlement in Scotland, and an Act of Parliament from 1809 which stipulated that "a church be built when there were five thousand inhabitants living in an area" (CALDWELL, 2000, p. 3), it fell to city authorities to build churches once a certain number of houses were built. The expansion eastwards of Edinburgh's New Town meant an additional church was needed in the planning applications. Obviously, no thought was given to the possibility of religious pluralism in the $17^{\text {th }}$ or $19^{\text {th }}$ centuries. It was also a different era of churchstate relations. The Reformation settlement in Scotland - a magisterial Reformation where it mattered that the civil magistrate, the political leaders, and public life were Protestant - ensured that city authorities built, and maintained, parish churches.

The parish has continually expanded. According the Presbytery of Edinburgh Presbytery Plan 2012-2022,

In terms of resident population the parish is the second largest in the Presbytery area with an estimated population in 2008 of almost 12,500 almost half of whom are in the young adult age group of 25 to 44 years. This compares to one-third in this age group for the city as a whole and correspondingly all other age groups, apart from those in the student (16 to 24 years) age group are less well represented. The parish population is therefore characterised by low numbers of children, significantly high numbers of student and young adults up to 44 years and fewer in the older and elderly age groups.

${ }^{13}$ A 'famous fact' in relation to this parish church is that Robert Louis Stevenson's grandfather, Robert Stevenson, was an Elder of St Mary's for fifteen years, from 1828 to 1843 . He was famous for his engineering achievements, being at that time Engineer to the Northern Lighthouse Board. Robert Louis Stevenson is author of the English language classic Treasure Island, and is famous for introducing the phrase Jekyll and Hyde into the English language based on a book by the same title. 
In an earlier reflection on parish ministry, I outlined the pluralism in this young and large parish,

Today, the parish has 12,000 inhabitants. A minority are Christian. According to the Census in 2011, while 15 percent of people who live in the parish responded to the Census question that they were affiliated to the Church of Scotland, rising to 37 percent for those identifying themselves more broadly as Christian, the single largest grouping in the parish - at 50 percent - is "no religious affiliation."14 In addition, there is a mosque which was firebombed after the 11 September 2001 attacks on US soil, and there is one of the most significant Baha'i faith centres in the world, because the city was visited by Abdu'l-Baha in 1913. (Abdu'l Baha was the eldest son of Bah'a'u'll'ah, who had formulated the principles of the Baha'i faith during his banishment from Iran in the late 19th century. ${ }^{15}$ ) There is also a Jewish diaspora, although the two synagogues in the city are not located in the parish bounds. Furthermore, 16 percent of the inhabitants speak a language other than English in the home ${ }^{16}$. It is a very different parish from that envisioned by the 1809 Act of Parliament for building ecclesiastical buildings and the 1921 Articles Declaratory setting out the distinctive vocation of the Church of Scotland (MCGEOCH, 2016).

Religious pluralism is more visible through buildings, habits or beliefs. The parish has 11 other churches within its bounds (not including house churches) and the Roman Catholic Cathedral on the parish boundary, which obviously served significant minority of Roman Catholics living in the parish ${ }^{17}$. Not all church architecture is the same, nor is it necessarily distinctly 'church architecture' in the parish. For example, the churchplant supported by a US missionary association meets in a unit in a small industrial estate and the Christadelphian church is located in a Victorian townhouse. The same can be said for the mosque, which is located in a converted carpet factory, and the Bahi'a faith centre is located in a Georgian townhouse. In addition, of course, not all expressions of religious pluralism are restricted to 'places of worship'18.

\footnotetext{
${ }^{14}$ See: http://cos.churchofscotland.org.uk/resources/statistics_for_mission/parish_profiles/010008.pdf

${ }^{15}$ CARVALHO; MARTINS, 2006, p. 207.

${ }^{16}$ See: http://cos.churchofscotland.org.uk/resources/statistics_for_mission/parish_profiles/010008.pdf

${ }_{17}$ These included two Scottish Episcopal churches, two Baptist churches, an independent evangelical church with Brethren origins, a church-plant supported by a US missionary association, a missional community supported by an independent evangelical church, a meeting of the Religious Society of Friends (Quakers), a United Methodist church (offering worship in Shona), and a Pentecostal church (offering worship in Portuguese). There is also a Christadelphian church (a Unitarian church).

18 'Places of worship' is clearly a Christian term, even if sometimes used in Religious Studies and other literature to designate church, mosque and synagogue. Such 'places of worship' play different roles in Christianity, Islam and Judaism, and indeed are conceived of differently by each community.
} 
Stefano Bonino documents this growing visibility of the 'religious other' in his research into Muslims in Scotland. His research demonstrates that there is a Muslim presence in all of Scotland's local authorities although the Muslim population is heavily concentrated in Scotland's largest city, Glasgow (BONINO, 2017). This cultural and religious pluralism is contributing to evolving debates about Scotland and the kind of country it wants to be. However, the political narrative is often embedded within the wider 'Western' context post-2001 (and post-1989 Rushdie fatwa). In other words, Islam is frequently 'exotic other'. In the language of Scotland's leading historian - Tom Devine - Islam forms part of the community of 'new Scot'.

This fact challenges the Reformation settlement in Scotland. It was brought into sharp focus following the 'double referenda' in the UK 2017 (membership of the European Union) and 2014 (membership of the UK). Matthew Ross observed that,

the decline of industry and manufacturing, the achievement of the Scottish Parliament with legislative competence, a referendum on independence, secularization, immigration and the corresponding rise of other faith communities have changed Scotland in ways barely imaginable in earlier decades (ROSS apud BARROW; SMALL, 2016, p. 134).

He goes on to note that, "the future of religion and belief in Scotland appears to be one of ever-greater diversity" (ROSS, 2016, p. 138). Stefano Bonino's pioneering study Muslims in Scotland (BONINO, 2017) echoes Ross' 'Christian' observation from a Muslim perspective. While Muslims account for $1.4 \%$ of the total Scottish population and are highly concentrated in Glasgow (representing $42 \%$ of the total Muslim population total) (BONINO, 2017, p. 24), there is a Muslim presence in every Scottish region. In other words, all presbyteries in Scotland have a Muslim presence, and very likely other expressions of faith within their bounds. This being the case, the pluralism described above with relation to a parish church in an urban centre is not an exception. It is possible to affirm that pluralism touches every parish in Scotland.

Even where the 'religious other' does not live in the same street, $\mathrm{s} / \mathrm{he}$ is present in the society. As Tom Devine and Angela McCarthy have pointed out, 'new Scots' are involved in Scotland's political, economic, social and cultural life, often contributing and shaping Scottish imaginaries. 'New Scots' is a term that engages with "international mass migration" (DEVINE; MCCARTHY, 2018, p. xiii), and has been used to describe 'new 
immigrants' to Scotland. It is a term that captures migration movements and their relation to Scotland. Devine and McCarthy have noted that the 1911 Census recorded that almost $10 \%$ of the population in Scotland had been born outside the country, and that the largest groups of new Scots were Roman Catholic and Protestant Irish, English, Lithuanian, Poles, Italians and Jews (DEVINE; MCCARTHY, 2018, p. 15).

After World War I, emigration dominated Scotland's landscape and the English replaced the Irish as the largest single group of new Scots. After the Second World War, and facilitated by the 1948 Nationality Act which enable the settlement of migrants from colonies and former colonies, migration from South Asia (India, Pakistan and (hina), Africa and the Caribbean, and also central and Eastern Europe added to the new Scots. The expansion of the European Union in 2014, and the ascension of 8 new countries, brought Poles, Lithuanians, Estonians, Latvians, Czechs, Slovakians, Hungarians and Slovenians to Scotland (DEVINE; MCCARTHY, 2018, p. 7).

\section{Pluralism and Scottishness}

William Mcllvanney commented on a street march in a parish somewhere in Scotland that it is a 'mongrel nation'. While this possibly hints at national pluralism, (and recent civic national discourse builds adroitly on Mcllvanney's lyricism), we might ask if this 'mongrel nation' harbours any notions of religious pluralism. The sociologist David McCrone has described a Scottishness refashioned in the $19^{\text {th }}$ century "around three identity pillars of Church, state and empire" (MCCRONE, 2001, p. 158). "New Scots' arrived into this institutional arrangement whereby Church, state and empire were Protestant and white. The $20^{\text {th }}$ century witnessed a breakup of Protestant hegemony, political unionism, and imperialism, leading McCrone to conclude that more pluralistic notions of Scottishness emerged in this period (MCCRONE, 2001, p. 169). This culminates in a Scottish parliament, which helps to shift debates on Scottish identity away from allying with a disappearing national church, fragmenting unionism, and obsolete empire towards concepts of 'civic nationalism' rooted in birth, descent and residency. To be Scottish, it is no longer necessary to be Protestant, unionist and imperial (or white). 
Mindful of Macllvanney's warning against "identify[ing] our Scottishness in wilful fragments" ${ }^{19}$, the qualifying details of context are important for understanding religious pluralism in parish ministry. They are particularly important because recent theological reflection in the Church of Scotland has wrestled with the struggle of being Presbyterian and pluralist in parish ministry. Doug Gay's Chalmers Lectures outlined a route to reform for the Church of Scotland. He is not the first 'insider' to offer such a reflection to the church ${ }^{20}$. However, it is by far the most theologically comprehensive perspective that is also widely read by people in and beyond the church.

Gay's work has previously fruitfully engaged theologically with the ethics of (civic) nationalism from an Augustinian perspective. Writing in the lead up to the Scottish Referendum on membership of the UK, Gay developed a theology of civic nationalism. His ethics of (civic) nationalism and ethics of (Augustinian) love begins with a renunciation of imperialism, a renunciation of (biological and territorial) essentialism, and a renunciation of absolutism (GAY, 2013, p. 81). Gay follows Oliver O'Donovan and Stanley Hauerwas, although he is more attracted to O'Donovan's practical political theology which invites Christians to renounce State and Nationalism. Gay renounces nationalisms of power, in favour of nationalisms of virtue. This is where Augustine's ethics of love prove useful to Gay's argument about virtuous nationalism, better understood as civic nationalism. The biggest challenge from this form of theological civic nationalism to parish ministry is obviously territorial essentialism. I will return to this issue.

Gay`s work has also fruitfully engaged theologically with Presbyterianism, attempting to avoid (what he calls) the 'pitfalls' of Episcopalianism and Congregationalism (GAY, 2017, p. 30). While Presbyterianism sits uneasily but truly with Gay - this is in part due to his Brethren/Congregationalist background - his observations are pertinent to a territorial Presbyterianism. Gay argues convincingly that Presbyterianism is not restricted to church polity. It is about layers and levels of governance (2017, p. 33), representative and participatory democracy (2017, p. 35),

\footnotetext{
${ }^{19}$ William McIlvanney's original opinion article was published in The Herald, 6th March 1999. The reference in this text is taken from McCRONE, 2001, p. 128.

${ }^{20}$ Another attempt by an 'insider' is MACDONALD, 2017.
} 
unity (2017, p. 37) 21 $^{21}$ and demanding discipleship (2017, p. 38). This Gay views as both empowering and exhausting, historically. I agree. But, is it is definitively empowering in terms of religious pluralism. Moreover, this empowering is linked to his next observation about 'the meenister' (2017, p. 40). The analysis is rather Lacanian and subject to accusations of collective delusion. However, in the parish system, 'the meenister' is an imagined representative of Scottishness, and, at the same time, a potential doorway into religious pluralism that is not simply secular reductionism.

My experience in a parish is that the 'religious other', particularly in the guise of Islam and Judaism, welcome the religious presence of 'the meenister' and the parish church precisely because they are a virtuous counter weight to secular power. A parish geography is a religious geography and the 'religious other' (the 'new Scot' even) can navigate this geography with the maps from his/her own religion. (For example, the Central Mosque in Glasgow relating to the Central Church in Glasgow, as quoted above). This provides solace and welcome to many. 'We know you pray for us', is a comment that I have heard from more than one rabbi or imam, Jew or Muslim, in relation to the parish church. This matters. The political ward - Westminster or Holyrood - is not likely to maintain this Reformation tradition of prayer for the parish, unless the elected representative is confessionally religious. Furthermore, churches which do not operate a parish ministry are not obliged to follow this pattern of prayer and church order.

Gay has consistently served parish ministry in a variety ways alongside his work as a practical theologian at the University of Glasgow. In his Chalmers Lectures, his final, 'less predictable' reform relates to his observation of the growing 'congregationalisation' of the global church (GAY, 2017, p. 169). He bases this affirmation on Miroslav Volf's ecclesiology. Volf notes,

Just as significant as the rapid growth of these Free Churches, however, are the incipient structural transformations within the traditional Protestant and Catholic churches, which are undergoing a process of growing 'congregationalization' even where this process has not been accommodated ecclesiologically (VOLF, 1998, p. 12).

\footnotetext{
${ }^{21}$ Gay curiously investigates how difficult it is to leave a Presbyterian church, when surely the point is it aspires to unity in God, and thereby unity in God's created order.
} 
Both Gay and Volf grew up in Free Church contexts Gay uses Volf's observation to advocate a form of 'congregationalisation' that seeks to overcome 'aristocratic presbyterianism' which prides itself on its layered court system at the expense of legal or constitutional congregational empowerment. Again, Gay's observation is true in relation to the operation of Presbyterianism in Scotland's churches. However, Presbyterianism is about broader visions for church and society (which 'congregationalisation' cannot effectively address).

Gay's use of 'congregationalisation' is also differs slightly from Volf. Volf understands the process of 'congregationalisation' as clear and irreversible and locates it as the bubbling of restless spiritual energy over against clericalism, professionalism and hierarchy (VOLF, 1998, p. 13). However, in Gay's 'congregationalisation' with strengthened roles for both congregational meetings and presbyteries (excellent ideas in and of themselves), the congregational meeting is clearly the place of the bubbling of restless spiritual energy while the reformed presbytery get a 'professional' moderator and clerk. This counters Volf's empirical observation, and Gay draws both the bubbling of restless spiritual energy, and clericalism, professionalism and hierarchy into distinct Presbyterian spheres. In this guise, congregationalisation can quickly become congregationalism. The difficulty with 'congregationalisation' susceptible to congregationalism is that it cannot effectively address 'the religious other' unless one's congregation is predisposed. The 'foil' for Presbyterianism may well be fear of congregationalism. However, the same is not true for in reverse for congregationalism. Its 'foil' is not Presbyterianism but frequently the 'religious other'.

To recall Diana Eck's question, 'how do we relate to one another?' in relation to three groups: scholars, citizens and faith communities? Generally, congregationalism is virtuous in its engagement with scholars and citizens. It can fairly comfortably work within the religious pluralism advocated by State secularism. It need not give credence to the religious other as religious, although it may choose to do so. The question of religious pluralism for congregationalism is much more difficult at the level of habits 
or beliefs, than buildings. The presence of the 'religious other' is almost a given. The significance of the 'religious other' is contentious.

By contrast, Presbyterianism - which is not primarily about church courts - looks to the broader layers and levels of governance of a parish, representative and participatory democracy, unity, and demanding discipleship. I do not want to set up a Caledonian antisyzygy between congregationalism and presbyterianism ${ }^{22}$. However, I do want to suggest that parish ministry in this broader understanding of presbyterianism is invitational to 'the religious other', who frequently in the guise of 'new Scot' does not have a map for the secular order and prefers a religious settlement. In this sense, we might now return to our earlier questions, does a 'national church' help or hinder the framing of narratives of religious pluralism? Furthermore, we might explore, how does a 'national church' bring the ordinances of religion to Jews or Muslims?

\section{Answering the challenges of religious pluralism}

There appear to be three broad challenges to parish ministry with regard to religious pluralism. Partly, this is due to the challenging critiques of territorial essentialism. Gay's renunciation of this aspect of nationalism more broadly obviously also (inadvertently?) sweeps away aspects of a church's self-understanding of its territory (whether parish or mission). At the close of his book Reforming the Kirk, he is wary of the implicit imperialism in parish ministry. He also, deftly, draws on Reformed and Puritan sources - Abraham Kuyper, amongst others - to draw in the concept of the dominion of Christ in relation to territorial imaginaries. However, it is the provisionality of nationalism, more fully treated in his early work, Honey from the Lion, and more comprehensively drawing on Oliver O'Donovan's political theology, which enable Gay to try to commit to parish or mission, while critiquing territorial essentialism in ecclesiology.

\footnotetext{
22 'Caledonian antisyzygy' is frequently associated with Scottish writer Hugh MacDiarmid. However, it actually traces its roots to early $20^{\text {th }}$ century. It is often used to describe dueling polarities in the same entity, expressing something of the Scottish temperament.
} 
The first challenge to parish ministry is that Christianity is more catholic (universal) than Protestant. In other words, many approaches to religious pluralism in the parish church are premised on Protestant theologies and Presbyterian governance. In a parish ministry, one in the context of a declining church with increasing congregationalist tendencies it is all too easy to engage in religious pluralism the way one does with a ball in a park: 'it's ma ba, and yer no having it'. Protestantism obviously brings its own gifts to religious pluralism, but it is necessary to remember the religious pluralism within religions not only amongst religions.

The second challenge is the public place of religious pluralism. The European Enlightenment project tried to remove religion from the public space, reducing it to (at best) a private good. The revanche de Dieu, the return of religion to the public space is a challenge for scholars, citizens and faith communities (and also for public authorities $)^{23}$. It is a challenge to faith communities to contrast what the theologian Miroslav Volf has called religious political pluralism with religious totalitarianism (VOLF, 2013). Religious political pluralism acknowledges that faith informs visions and actions in the public space, but it does not advocate imposing religious rules. At the same time, it is a challenge for public authorities to engage faith communities as just that, faith communities, not interest groups, pressure groups, lobby fodder, etc. There is further work needed on developing the concept that religious pluralism is not a specialised field only for scholars of faith communities. There is also further work needed on understandings of the 'public'. Not all 'new Scots' bring this Enlightenment understanding of the place of religion in society. The parish ministry - a Reformation leftover - is a gentle reminder that not all of Europe's imagination was swept up in the Enlightenment project, too. The parish is public, but not a secular public.

The third challenge is to continue to find ways for religious pluralism to express itself in buildings, habits and beliefs. Cityscapes are changing. The bell tower of the parish church is no longer the highest building, nor is it always the defining landmark in a parish. In banking and industry, parishes find new landmarks. What of mosques, synagogues and others? And what too of habits when the Muslim in my street is

\footnotetext{
${ }^{23}$ As already mentioned in an earlier section, Eck, Cornille and others would question the usefulness of social science theories of 'secularisation' and 'revanche de Dieu' in addressing 'religious pluralism'.
} 
rejected as a Muslim because $\mathrm{s} /$ he does not follow the massified Islamic precepts, or does not dress according to hegemonic religious discourses? How do we encounter and experience religious pluralism outside of the strict category of religion? A parish geography provides for this.

A parish church also provides for an exploration of beliefs. For example, in my parish ministry in Glasgow, Lisbon and Edinburgh, I have opted to explore religious pluralism in the context of worship - by visiting places of worship and by ensuring that other religious leaders and people experience directly a diet of (Christian) worship. This includes both men and women (and children) of other religions. Invitations from the church to diets of worship have always insisted that the invitation be extended to both men and women. Mosque and synagogue have always accepted invitations on this basis, and Christians, Muslims and Jews both men and women have prayed together without segregation in the church. On these occasions worship has intentionally included multiple voices - lay and ordained, men and women - in different aspects of the liturgy. This is, I believe, good for our church and at a deeper level will hopefully inform and challenge how we think of our Christian faith amidst religious pluralism.

Although, I have engaged with other religions beyond Islam and Judaism, it is with Islam and Judaism that parish ministry has advanced further ${ }^{24}$. In part, this is due to the monotheism that binds Christianity, Islam and Judaism. A love of God is as good a place as any to begin to explore religious pluralism. It is also the one fundamental area that provides difficulty for non-religious perspectives of religious pluralism, and it is one that also has a greater difficulty to emerge in a Scotland without the parish church.

\section{Conclusion}

Parish ministry is part of past 'Scottishness', it is also part of future religious pluralism. While a parish ministry is always hostage to power relations - in history and in practice - it can also be hospitable terrain. A 'mongrel nation' and a 'mongrel mission

\footnotetext{
${ }^{24}$ I have engaged in similar practices as described in this reflection with Afro-Brazilian religions, Buddhists, Hindus, and Pagans.
} 
church' (as a reflection of that nation), require territorial maps and imaginaries that are not simply imposed public secular reason. Religious pluralism is more apparent today to scholars, citizens and faith communities. It is present in the streets where we live and in the parishes where we live, work, and seek leisure/refuge. It is more visible in buildings, habits and beliefs in parishes.

Religious pluralism presents us with Diana Eck's question, 'how do we relate to each other?' It also requires us to remember rightly how we have in the past related to each other. Religious pluralism is Europe is littered with violence and persecution. Pluralism may now be set out as a political and cultural project, but it is also a religious vocation rooted in love of God and love of neighbour. It is, to borrow Doug Gay's phrase, a virtuous pluralism rather than a pluralism of power. Just as he has suggested the need to detoxify nationalism and hold our the theological provisionality of any national church, I would like to refashion the parish ministry in 'decolonial' terms. It is no longer an exclusive place of Christians, nor even protestants. But in its religiously imagined territory it has elective affinities with other religious worldviews. In this, it requires a parish church - as a legacy of the Reformation settlement - to actually find ways of being a parish church when the presumptions of by gone days no longer fruitfully fulfil the aspirations of scholars, citizens, and faith communities in all their expressions of religious pluralism.

I have learned that a church building can be a 'prayer room' for a Muslim. I have learned that a synagogue liturgy gives us access to the reality of the early disciples. I have seen Christian, Jew and Muslim realise that the One God is common to all three religions, even if we sometimes hurtfully (and hatefully) express this differently. And in parish life, I have learned that most expressions of religious pluralism are not captured fully by formal religious belonging to building, habit or belief. The parish, rather than the political ward, holds out hope for exploring this form of religious pluralism because it introduces to 'new Scots' a territorial map that echoes some their own religious navigation of the world. 


\section{Bibliography}

ARMSTRONG, K. Twelve Steps to a Compassionate Life. New York: Knopf, 2010.

BARROW, S.; SMALL, M. Scotland 2021. Edinburgh: Ekklesia \& Bella Caledonia, 2016.

BONINO, S. Muslims in Scotland. Edinburgh: Edinburgh University Press, 2017.

CARVALHO, M. P.; MARTINS, J. M. (eds.). Religiões: História, Textos, Tradições. Prior Velho: Paulinas, 2006.

CALDWELL, J. W. B. A History of St Mary's Parish Church Edinburgh 1824-1992. Edinburgh: [s.n.], 2000. (Mimeograph).

CHARTA OECUMENICA: Guidelines for the Growing Cooperation among the Churches in Europe. Geneva: CEC Publications, 2001.

CORNILLE, C. (ed.). Women and Interreligious Dialogue. Oregon: Cascade Books, 2013.

CORNILLE, C. (ed.). Interreligious Dialogue and Cultural Change. Oregon: Cascade Books, 2012.

CORNILLE, C. (ed.). The World Market and Interreligious Dialogue. Oregon: Cascade Books, 2011.

CORNILLE, C. (ed.). Interreligious Hermeneutics. Oregon: Cascade Books, 2010.

CORNILLE, C. (ed.). Criteria of Discernment in Interreligious Dialogue. Oregon: Cascade Books, 2009.

DEVINE, T.; McCARTHY, A. New Scots: Scotland's immigrant communities since 1945. Edinburgh: Edinburgh University Press, 2018.

ECK, D. The Gifford Lectures 2009: "The age of Pluralism". https://www.giffordlectures.org/lecturers/diana-eck.

GAY, D. Reforming the Kirk: The Future of the Church of Scotland. Edinburgh: St Andrew's Press, 2017.

GAY, D. Honey from the Lion: Christianity and the Ethics of Nationalism. London: SCM Press, 2013.

MACDONALD, F. From Reform to Renewal: Scotland's Kirk Century by Century. Edinburgh: St Andrew's Press, 2017.

MACLEAN, M. A. The Crown Rights of the Redeemer: The Spiritual Freedom of the Church of Scotland. Edinburgh: St Andrew's Press, 2009.

MCCRONE, D. Understanding Scotland: the sociology of a nation. London: Routledge, 2001. 
McGEOCH, G. What Happens when History does Walk as Wish? A moving spirit and transformational discipleship in a parish church. International Review of Mission, v. 105, n. 2, p. 184-195, 2016.

ORDERS, D’A. St Andrew's Presbyterian Church. Lisbon: British Community Series, 1990.

PUI LAN, K. Globalization, Gender, and Peacebuilding: The Future of Interfaith Dialogue. New York: Paulist Press, 2012.

PURVES, J. W. An Island Story: The Scots in Madeira. Edinburgh: Church of Scotland Publications, 1940.

RABBANI, H. Christian-Muslim Dialogue: Encounters with a Christian Minister. In: SHIMADA, L. D. (ed.). Mapping Faith: theologies of migration and community. London: Jessica Kingsley Publishers, 2020.

REEVES, D. Religious Upbringing and Contemporary Challenges in a Globalised Era. In: ANNUAL CONFERENCE OF DOHA INTERFAITH DIALOGUE, 8., 2010. (Unpublished manuscript).

RIBEIRO, C. O. Pluralismo e Libertação. São Paulo: Paulinas, 2014.

ROSS, M. Religion and Belief in Scotland. In: BARROW, S.; SMALL, M. Scotland 2021. Edinburgh: Ekklesia \& Bella Caledonia, 2016. p. 134-138.

TESTA, M. P. Robert Reid Kalley: O apóstolo da Madeira. Lisboa: IEPP, 2005.

VOLF, M. 2011. A Public Faith. Grand Rapids: Brazos Press, 2013.

VOLF, M. After our Likeness: the Church as the image of the Trinity. Grand Rapids: W.B Eerdmanns, 1998.

WENINGER, M. H. Uma Europa sem Deus? Lisboa: Edições 70, 2009.

RECEIVED: 09/29/2020

RECEBIDO: 29/09/2020

APPROVED: $11 / 17 / 2020$

APROVADO: $17 / 11 / 2020$ 